\title{
Value Chain Analysis of Marine Ornamental Fish Industry in the Philippines
}

Frederick B. Muyot ${ }^{\star 1}$, Maria Theresa M. Mutia ${ }^{1}$, Arvie Joy A. Manejar ${ }^{1}$, Gency L. Guirhem ${ }^{1}$, Margielyn J. Muñez ${ }^{1}$ National Fisheries Research \& Development Institute-National Freshwater Fisheries Research and Development Center, Brgy. Butong, Taal, Batangas,

\begin{abstract}
A B S T R A C T
The Philippines is a major supplier of marine ornamental fish in the world but the understanding of the overall local industry is limited. This study assessed the marine ornamental fish industry in the Philippines using the value chain analysis approach aimed to describe the market chain and key actors, species collected and traded, cost distribution in each of the stakeholders involved, and value addition across actors. Survey interview using purposive sampling was conducted in major collection areas in the country and data gathered was analyzed through a mixed-methods approach and validated by focus group discussions. The results identified the actors in the chain as diver-gatherer, middleman-trader, and exporter. There were 1,431 stakeholders directly dependent on the industry. The annual trade approximately involved a total of $8,554,729$ pieces comprised of 1,200 marine species belonging to 144 families contributing PHP 235,496,302.50 to the country's economy. The bulk of the supply came from Region 4A (61.06\%), Region 3 (26.63\%), and Region 7 (5.32\%). The value chain of the industry was mapped out, revealing a gross value addition of PHP 88.27 per marine ornamental fish. Cost-return analysis showed the last node actors having the highest monthly net return while the lowest in the first node actors. Appropriate programs, policy, and institutional reforms needed to maximize the benefits of the business across key actors and ensure the sustainability of fish resources in the wild were presented.
\end{abstract}

E-mail address: fredbmuyot@yahoo.com*

Received: October 29, 2018; Accepted: December 22, 2018

Keywords: marine ornamental fish, value chain analysis, ornamental trade

\section{I N T R O D U C T I O N}

Q rnamental fish keeping is the second largest hobby in the world with interest in aquarium fishes appear to be growing continuously. It is a multibillion-dollar industry with an increasing trend for demand equivalent to USD 10 billion (Dey 2016). The industry is composed of two sectors: freshwater ornamental and marine ornamental fish sector, which involves trading of around 2,000 freshwater and marine species annually, $65 \%$ of which is being met by Asia (Livengood and Chapman 2009; Ling and Lim 2005). Demand for ornamental fishes is steadily increasing with more than USD 15 billion annual total trade (FAO 2015). Reported export value is USD 370 million while the import value is USD 350 million. The wholesale value is worth USD 1 billion while the retail value is USD 3 billion. Being a lucrative business, many countries are engaged in the production of ornamental fish. Asian countries like Singapore, Sri Lanka, Malaysia, and Thailand are major producers of ornamental fish with significant export trade (Ling and Lim 2005; Herath and Wijewardene 2014). The total import value of marine ornamental fish range between USD 28-44 million in the 1990s. About 45 countries supply the market, with the most important suppliers being Indonesia and the Philippines while Brazil, Maldives, Vietnam, Sri Lanka, and Hawaii are also supplying significant quantities (Wood 2001).

In the marine ornamental fish sector, the Philippines enjoys a substantial part of the trade regarded as one of the largest exporters of marine ornamental species in the world (Orchavillo et al. 2004). Export trade of live marine ornamental fish of the country averaged 5,216 MT valued at PHP $279,479,000$ (USD 558,958) for the period 2009-2016 representing about $0.80 \%$ of the export trade of the country (PSA 2016). The marine ornamental fish 


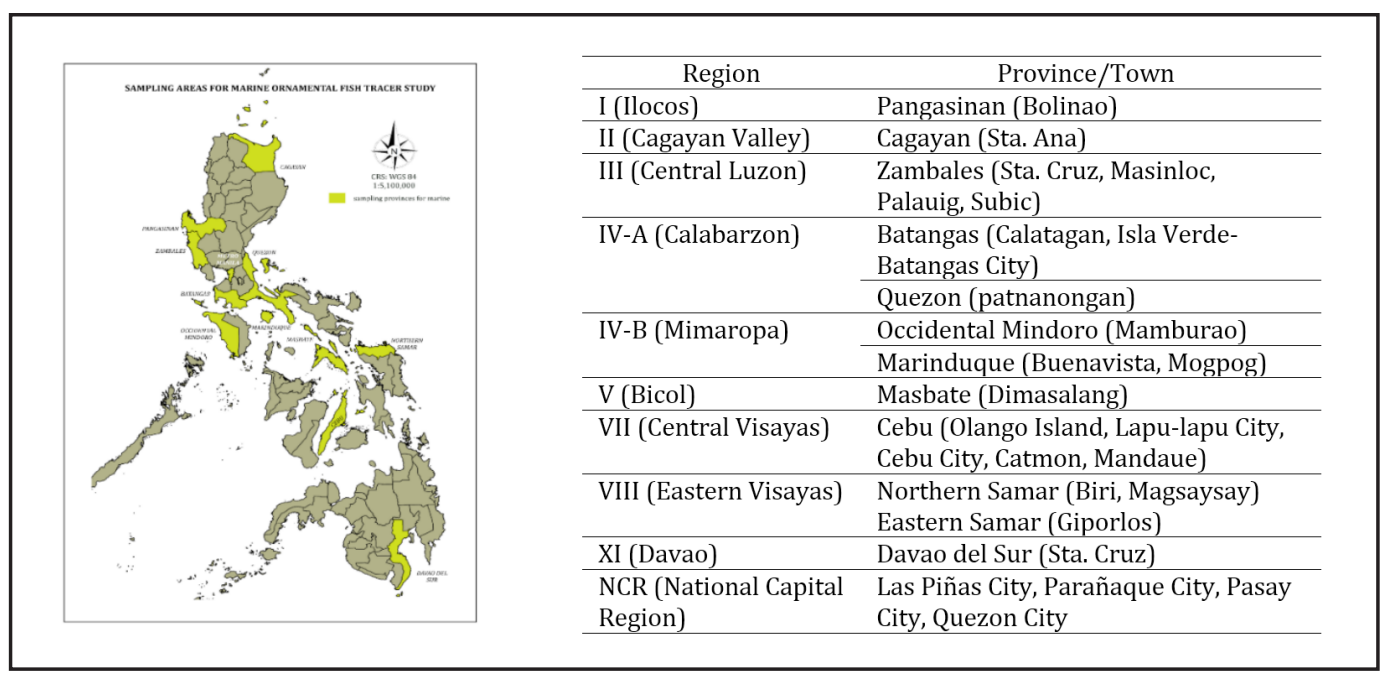

Figure 1. Survey areas for the value chain analysis of marine ornamental

fish industry in the Philippines

sector mainly involved the gathering of wild, native, and endemic species from coral reef areas and traded mainly for the export market. This put strong pressure on the wild populations (Bruckner 2005). Despite its contribution to export trade, the marine ornamental fish sector had been criticized for an unsustainable harvest of fish from its habitats and the illegal use of cyanide which had made a negative impression on the sector. An alternative source of marine ornamental fish, captive-bred ornamentals produced through aquaculture, is an emerging trend in the international marine ornamental fish trade (Swet and Pedersen 2018) but the Philippines has not made any attempt on this field. There is a wide opportunity for livelihood and trade for marine ornamental fish but particular issues and concerns of the sector have to be identified and addressed to achieve maximum benefit from the industry while ensuring sustainability of marine fishes in the wild.

Government initiatives on commodity species like ornamental fish are crucial to the development of the industry. Over the past decades, the Bureau of Fisheries and Aquatic Resources (BFAR) had initiated programs and policy thrusts for the ornamental fish industry. Recently, the Comprehensive National Fisheries Industry Development Plan (CNFIDP) 2016-2020 was developed to facilitate the development of the various sectors in the fisheries industry in terms of production, research, and development (CNFIDP 2016). This included the ornamental fish sector. However, the lack of comprehensive baseline information on this sector makes it difficult to ascertain the appropriate avenues to address challenges in the industry. Thus, a study along this line was conducted to provide the needed information. This study described the market chain and key actors of the marine ornamental fish trade in the Philippines, species collected and traded, cost distribution in each of the stakeholders involved, and value addition across actors for appropriate recommendations for programs, policy, and institutional reforms. Moreover, the study presented upgrading strategies and action plans to maximize the benefits of the industry to each of the actors in the chain and the whole sector in general.

\section{MATERIALS AND METHODS}

The study covered Luzon, Visayas, and Mindanao involving 23 municipalities and 6 cities in 13 provinces belonging to 10 regions in the Philippines (Figure 1). The study areas were identified as major collection sites for marine ornamental fish based on key informant interviews with government agencies and exporters of marine ornamental fish in the country (Table 1). Information on the stakeholders of the marine ornamental fish was limited to the list of accredited exporters from BFAR, the lead fisheries agency in the country. This list was requested from BFAR and was used as a lead point in tracing the stakeholders of the industry. Of the forty-seven marine ornamental fish exporters accredited by BFAR, thirteen Manila-based and two Cebu-based exporters were interviewed for the study. From the interview of the exporters, the contact details of middlemantraders transacting with them were willingly given. These middleman-traders were contacted and asked 
Table 1. Respondents for the Key Informant Interviews and Focus Group Discussion (FGD)

\begin{tabular}{|l|l|}
\hline \multicolumn{1}{|c|}{ Category } & \\
\hline A. Key Informant Interview \\
\hline BFAR Regional Offices & BFAR Regions I; II; III; IV-A; IV-B; V; VII; VIII; XI \\
\hline Local Government Units & $\begin{array}{l}\text { LGUs of Bolinao, Pangasinan; Sta. Ana, Cagayan; Sta. Cruz, Masinloc, Palauig } \\
\text { \& Subic of Zambales; Calatagan \& Isla Verde of Batangas; Real \& Patnanongan } \\
\text { of Quezon; Mamburao, Mindoro; Buenavista \& Mogpog of Marinduque; } \\
\text { Dimasalang, Masbate; Olango Island, Lapu-lapu City, Catmon, Cebu City \& } \\
\text { Mandaue City of Cebu; Capul, Biri \& Magsaysay of Northern Samar; Giporlos, } \\
\text { Eastern Samar; Sta. Cruz, Davao del Sur }\end{array}$ \\
\hline BFAR Main Office/s & $\begin{array}{l}\text { BFAR Fisheries Regulatory \& Quarantine Division; BFAR Fish Health; BFAR- } \\
\text { One Stop Export Documentation Center }\end{array}$ \\
\hline Exporters & $\begin{array}{l}\text { Aquahab Worldwide Inc.; Aquascapes Philippines Co.; Franz Eugenio } \\
\text { Inoc; Franz Eugenio Inoc Jama Aquatics (Transpacific); JEE; Marine Angel } \\
\text { Enterprise; Marine Aquaria Fish Trading; Marine Habitat International Export } \\
\text { Facility; N Tropical Marine Trading; Pure Marine Export; Re Pacific Quality } \\
\text { Trading, Inc.; STAR (Sharp Target Aquatic Resources); Sure Marine Products } \\
\text { Trading; Tou Boya; Cebu International Aquatic Export Inc.; Cebu-Mactan } \\
\text { Quality Marine Aquarium Fish (CMQMAF) }\end{array}$ \\
\hline B. Focus Group Discussion \\
\hline Calatagan, Batangas & 19 Diver-gatherers; 9 middleman-traders; 2 LGU \\
\hline Olango Island, Cebu & 22 Diver-gatherers; 8 middlemen-traders; 3 exporters; 2 LGUs; 1 BFAR VII \\
\hline
\end{tabular}

for permission for an interview. All middlemantraders granted permission for an interview at a predetermined schedule. Moreover, the middlemantraders willingly provided the contact details of the diver-gatherers which were called upon through phone to ask permission for an interview, all of which gave permission. The survey interview in the study areas was conducted by regions at pre-arranged dates with the middleman-traders and diver-gatherers. For each region, a survey interview was conducted for a week for a duration of 1-2 days in each collection site. There was no available information on the population of the stakeholders of the industry, and this did not permit a random sampling. Purposive sampling was, thus, utilized for the survey since it did not employ a probability sample but instead focused on selecting particular individuals as stakeholders. This was intended to achieve representation or comparability per sector, in this case, stakeholder, similar to the methods employed by Teddlie and Yu (2007). The study interviewed 219 respondents composed of 138 diver-gatherers, 66 middleman-traders, and 15 exporters (Table 2).

Data were collected from January 2016 to August 2017, following three methods: survey interview, key informant interview, and focus group discussions (FGDs). Structured questionnaires were used for the survey with separate survey forms designed for each of the key stakeholders: divergatherers, middleman-traders, and exporters. The survey questionnaires were pre-tested in Calatagan, Batangas and modified based on the results of the pretest to come up with the final survey questionnaires. The finalized structured questionnaires gathered information on socio-demographics, collection areas, volume and value of production, type of species produced, and issues and concerns in livelihood and trade. During the actual survey, respondents were asked on the total estimated number of divers and middleman traders in the area. This information was used to estimate the total number of stakeholders and the estimated production of ornamental fish in the country. After the survey interview, two FGDs was conducted in Calatagan, Batangas and Olango Island, Cebu where key actor players were gathered together including divers-gatherers, middlemen, exporters, local government unit, and BFAR. During the FGD, data results were presented for validation by the participants. A SWOT analysis was also conducted to get insights into marketing scenarios and generate information on issues and concerns by each key actor player. Based on these pieces of information, upgrading 
Table 2. Number of survey respondents categorized into key actor players.

\begin{tabular}{|c|c|c|c|c|c|}
\hline Region & Provinces & $\begin{array}{l}\text { Diver- } \\
\text { gatherer }\end{array}$ & $\begin{array}{l}\text { Middleman- } \\
\text { trader }\end{array}$ & Exporter & Total \\
\hline I (Ilocos) & \begin{tabular}{|l|} 
Pangasinan \\
\end{tabular} & 8 & 2 & & 10 \\
\hline II (Cagayan Valley) & Cagayan & 9 & 2 & & 11 \\
\hline III (Central Luzon) & Zambales & 53 & 23 & & 76 \\
\hline IV-A (Calabarzon) & $\begin{array}{l}\text { Batangas, } \\
\text { Quezon }\end{array}$ & 40 & 17 & & 57 \\
\hline IV-B (Mimaropa) & \begin{tabular}{|l} 
Occidental \\
Mindoro, \\
Marinduque
\end{tabular} & 12 & 8 & & 20 \\
\hline $\mathrm{V}$ (Bicol) & Masbate & 2 & 1 & & 3 \\
\hline VII (Central Visayas) & Cebu & 5 & 7 & 2 & 14 \\
\hline VIII (Eastern Visayas) & $\begin{array}{l}\text { Northern } \\
\text { Samar, } \\
\text { Eastern Samar }\end{array}$ & 4 & 3 & & 7 \\
\hline XI (Davao) & Davao del Sur & 5 & 3 & & 8 \\
\hline $\begin{array}{l}\text { NCR (National Capital } \\
\text { Region) }\end{array}$ & $\begin{array}{l}\text { Las Piñas City, } \\
\text { Parañaque City, } \\
\text { Pasay City, } \\
\text { Quezon City }\end{array}$ & & & 13 & 13 \\
\hline Total & & 138 & 66 & 15 & 219 \\
\hline
\end{tabular}

strategies and action plan for the marine ornamental fish industry was generated in order to describe means to maximize the potential of the industry and ensure the sustainability of resources in the wild.

To fully capture the value addition of the industry, cost distribution of the stakeholders was computed. Cost items were categorized into two major categories: fixed and variable costs. The first category was defined as a set of expenses that remain constant over time regardless of the scale of production, basically the equipment used for production. Straight-line depreciation method was used to measure the depreciation rates of the fixed assets. On the other hand, variable costs changed over time but shift as the volume of production changes. Under variable cost were four subcategories of cost items: labor, intermediate, transport, and services and others. Labor costs are further divided into two: hired and household. The number of hours 'clocked in' by the household members vary across stakeholders, but the average time spent each day was assumed as one working day. Intermediate costs were incurred through any activity before, during, and after shipping the commodity from the source to its destination.
Transport costs include fuel and vehicles. Lastly, services and others were miscellaneous expenses that do not fall under any of the aforementioned divisions. All data were encoded in Excel (Version 15.0). The production data gathered from the survey were based on actual transactions made by the divergatherers and middleman-traders with transaction receipts willingly provided by the respondents. Value addition was acquired by subtracting the costs incurred during the process from the average price per piece. The computation of the value addition follows two assumptions to ensure the uniformity of data and to avoid skewed values. The first assumption holds that the number of pieces used for monthly transaction per stakeholder remains constant over time. The second one is that the price used in the computation falls between low and high-value species. The costs were first distributed across the average quantity per monthly transaction in order to derive the cost per piece. These expenses were then added up and subtracted from the average price per piece to get the total value added. Cost and return analysis were also used to validate the results of value addition. Various applications of IBM SPSS were used for the analysis of the study such as 
Table 3. Estimated number of stakeholder households involved in marine ornamental fish industry in surveyed areas in the Philippines.

\begin{tabular}{|c|c|c|c|c|c|}
\hline Region & Province & $\begin{array}{c}\text { Total no. of } \\
\text { stakeholders }\end{array}$ & $\begin{array}{c}\text { Number of } \\
\text { diver-gatherer }\end{array}$ & $\begin{array}{l}\text { Number of } \\
\text { middleman }\end{array}$ & Total \\
\hline I (Ilocos) & Pangasinan, & 35 & 30 & 5 & \\
\hline II (Cagayan Valley) & Cagayan & 41 & 30 & 11 & \\
\hline III (Central Luzon) & Zambales & 439 & 340 & 99 & \\
\hline IV-A (Calabarzon) & $\begin{array}{l}\text { Batangas, } \\
\text { Quezon }\end{array}$ & 531 & 390 & 141 & \\
\hline IV-B (Mimaropa) & $\begin{array}{l}\text { Occidental } \\
\text { Mindoro, } \\
\text { Marinduque }\end{array}$ & 36 & 23 & 13 & \\
\hline $\mathrm{V}$ (Bicol) & Masbate & 8 & 6 & 2 & \\
\hline VII (Central Visayas) & Cebu & 243 & 201 & 33 & 9 \\
\hline VIII (Eastern Visayas) & $\begin{array}{l}\text { Northern } \\
\text { Samar, Eastern } \\
\text { Samar }\end{array}$ & 47 & 35 & 12 & \\
\hline XI (Davao) & Davao del Sur & 11 & 8 & 3 & \\
\hline National Capital Region & Metro Manila & 40 & & & 40 \\
\hline Total & & 1,431 & 1063 & 319 & 49 \\
\hline
\end{tabular}

frequency and descriptive statistics functions which computed the average, minimum, and maximum amounts for certain variables. These results served to be the foundation of most observations and significant findings. General and specific market chains used by diver-gatherer to middleman-trader and middlemantrader to exporter were drawn and presented as figure drawings.

\section{RESULTSAND DISCUSSION}

3.1 Stakeholders of the industry

Based on the survey interview of respondents, the total number of stakeholders in each survey area was estimated. An estimated number of 1,431 stakeholders were directly dependent on the marine ornamental fish industry (1,063 diver-gatherers, 319 middleman-traders, and 49 exporters) as shown in Table 3. Majority of stakeholders were found in 3 regions, namely Region 4A-Calabarzon (38.42\%), Region 3-Central Luzon (31.77\%) and Region 7-Cebu (16.93\%), which collectively comprised $87.12 \%$ of all stakeholders. Diver-gatherers and middlemantraders were mainly located in remote rural areas in nearshore areas adjacent to collection areas. Exporters were concentrated in Region 7-Cebu and National Capital Region due to the presence of international airports in Cebu and Manila, which are the authorized airports for ornamental fish trade. Diver-gatherers, the main producers of marine ornamental fish, were mainly located in near-shore coral reef areas which are natural habitats of marine ornamental fish.

Total annual production of marine ornamental fish was estimated to be $8,911,879$ pieces valued at PHP 137,165,576 (USD 2,743,311). The bulk of marine ornamental fish production came from three regions, namely Region 4A-Calabarzon from provinces of Quezon and Batangas $(5,843,071$ pieces), Region 3-Central Luzon from the province of Zambales (2,065,866 pieces), and Region 7-Cebu from the province of Cebu (412,934 pieces) which collectively shared $93.38 \%$ of all marine ornamental fish in the country (Figure 4). In terms of value, the production in these three regions was $94.5 \%$ valued at PHP 104,696,140 with Region 4A, Region 3, and Region 7 share of $70.8 \%, 18.2 \%$, and $5.5 \%$, respectively.

\subsection{Supply chain and key actors interactions}

The general and specific supply chain of the marine ornamental fish is presented in Figure 2, which indicated the regions where the supply chain was recorded during the study. Key stakeholders in the industry were diver-gatherers, middleman-traders, and exporters. The diver-gatherer and middlemantrader made up the upstream part of the chain while exporters constituted the downstream part. In the 


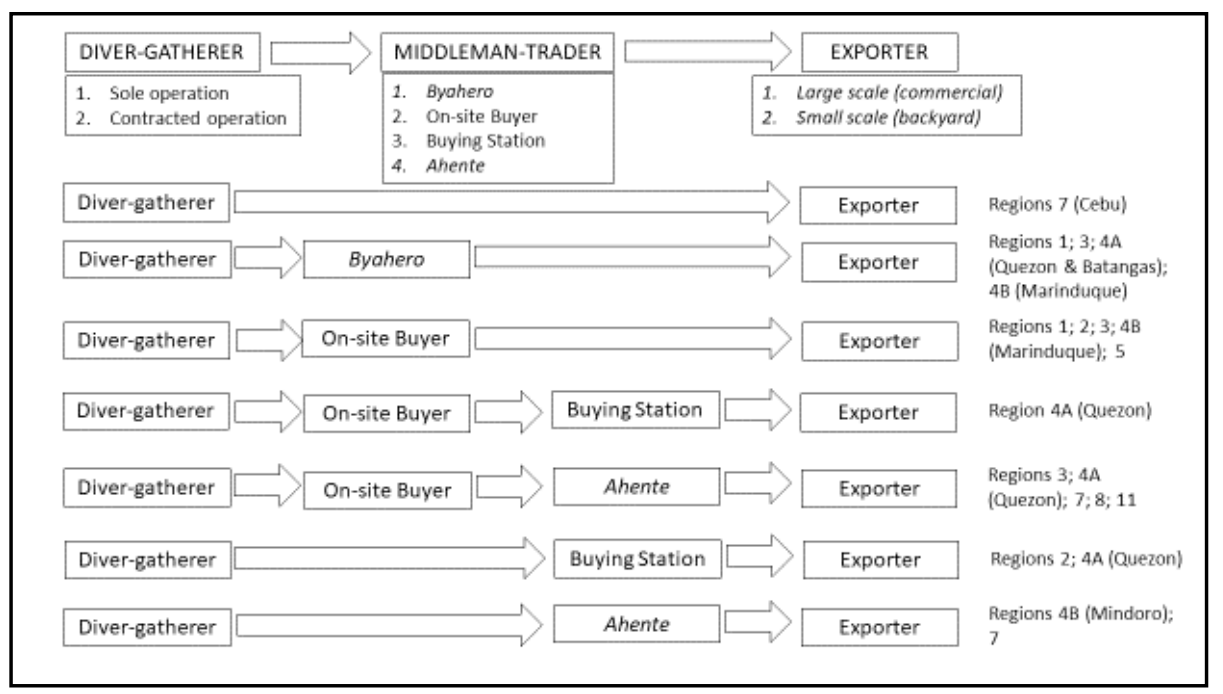

Figure 2. General and Specific Supply Chains of Live Marine Ornamental Fish in the Philippines

value chain, the downstream players possess the dominance and influence since they have greater purchasing power.

Diver-gatherers are the starting point of live tropical fish exports. As shown in Figure 1, these diver-gatherers can be divided into two. The first type were those operating alone or in groups that do not have any external connection in terms of trading with a mediator. They could trade the catch directly to the exporters by means of a byahero and also oftentimes with on-site buyers. However, all losses from gathering up to the delivery to the exporters are at the diver-gatherer's expense. The second type were those connected to on-site buyers. The involvement of this group turns over after diving. They were not concerned about mortality and transportation after collection because this was handled by on-site buyers.

Byahero is a type of middleman-trader who transports the commodity from the gatherers to the exporters. This part of the chain holds minimum risk for the only major activity is the transport of fish without taking the risk of mortality along the way. Byaheros' main source of income comes from the $10-20 \%$ commission from divers and another $5-10 \%$ commission and trucking allowance from the exporters. Payments to diver-gatherers by byahero was done upon return from delivery of fish and after being paid by the exporters.

On-Site Buyers is another middleman-trader who either finance or purchase marine ornamental fish from the divers in exchange for a guarantee that the diver-gatherer will only trade to him/her. On- site buyers had their own capital to purchase the fish from diver-gatherers on a cash basis at 20-30\% lower than the exporters' price. Because of the remoteness of fishing grounds and small individual catches, the trade requires middleman-traders who merge catches into sufficient quantities for export. There were two kinds of on-site buyer: the one directing the fish bought to exporters in Manila and the other one directing the fish to an export buying station. The latter will not bear the cost of mortality in the travel from the export buying station to the exporter. Middlemen who were identified as on-site buyers bear the costs of holding fish post-harvest losses where gatherers/divers themselves or spouses or a village resident got interested in the business. Competition among assemblers became tight during lean seasons (off-peak) as they also buy ornamental fishes from other places.

Ahente are middleman-traders who links onsite buyers of far-flung provinces of the Philippines to the exporters. These middlemen maintained residences near the exporters and facilitated the transfer of fish commodity from on-site buyers who cannot travel to Manila because of high transportation cost. The ahente were the ones who transport marine ornamental fish from ports to the exporting facilities. Unlike byaheros, these middlemen do not have an actual involvement until the commodity landed on ports. They also do not bear the mortality cost and transportation cost. Their job is to transportt from the port to the exporters. Ahente received 10-20\% commission and/or 5-10\% trucking allowance. 
A buying station is a direct link of the exporter to the divergatherer who purchase fish gathered by the diver-gatherer or from the middleman from the actual area of collection. This player is directly employed by the exporters whose primary aim is to decrease mortality during transport by ensuring proper conditions and treating fish diseases. The prices of ornamental fish in buying stations is the same as the price of exporters in Manila. However, if a supplier or a diver-gatherer choose to sell to buying stations, they cannot avail of a commission and trucking allowance.

Exporters were the main traders of live tropical aquarium fishes and dictated the price of fish per species. Within the Philippines, this was the final stop of the tropical fish before it will be exported. Two types of exporters were evident in the market. The first type was called major/commercial exporters. This kind of exporter has well-designed support facilities. This group was considered pioneers in this business because of advanced knowledge brought by long experience and exposure in the industry. The second type of exporters was called small-scale exporter or backyard exporter. These exporters have a simple life supporting system that pushes them to immediately dispatch the fish in a maximum of three days upon delivery. These exporters have a market in Asia where mortality risk in transport was lower compared to the large-scale counterparts.

\subsubsection{Marketing channels used by divers}

Figure 3 showed the specific supply chain of marine ornamental fish from the diver-gatherer to middleman-trader. Two of the main market channels used by the diver-gatherer were on-site buyer and byahero. About 39.29\% of the diver-gatherers sold their fish to on-site buyers and $34.22 \%$ to byaheros involving trades of $29.89 \%$ and $59.80 \%$, respectively. On-site buyers were present in all regions of the survey areas: Region 1 (Pangasinan), Region 2 (Cagayan), Region 3 (Zambales), Region A (Batangas and Quezon), Region 5 (Masbate), Region 7 (Cebu), Region 8 (Northern and Eastern Samar) and Region 11 (Davao del Sur). Byaheros, on the other hand, were present in Region

3 (Zambales), Region 4A (Batangas and Quezon), and Region 4B (Marinduque). The buying price of fish in these two channels was 10-20\% less than the exporter's price for byaheros (paid upon payment of byaheros by the exporter) and $20-30 \%$ less than the exporter's price for on-site buyers (paid in cash). On the other hand, the least used channel was through direct sale to the exporter $(7.11 \%)$ and buying stations $(5.78 \%)$. Only $2.13 \%$ of the traded fish were sold directly to the exporter and only $5.95 \%$ through the buying station. These market channels had the highest buying price of fish, which was at the exporter's price, and therefore provide higher profit margins for the divers. Such channels, however, were limited to areas where buying stations (from Cagayan and Quezon) and exporters (from Cebu City) were located near the collection areas. About $2.42 \%$ of collected fish were channeled through ahente by $13.6 \%$ recorded in certain remote areas in Regions 3 (Zambales), 4B (Mindoro), and 7 (Olango, Cebu) where transportation was difficult and could only be done through commercial shipping vessel. This channel entailed a higher cost for the divers who had to shoulder the transport cost up to the port where ahente will receive the shipment, but the diver-gatherer had no other option for trade due to the remote area.

\subsubsection{Market channels used by the Middleman-Traders}

The market channel used by the middlemantraders to reach the exporters (Figure 4) indicated 


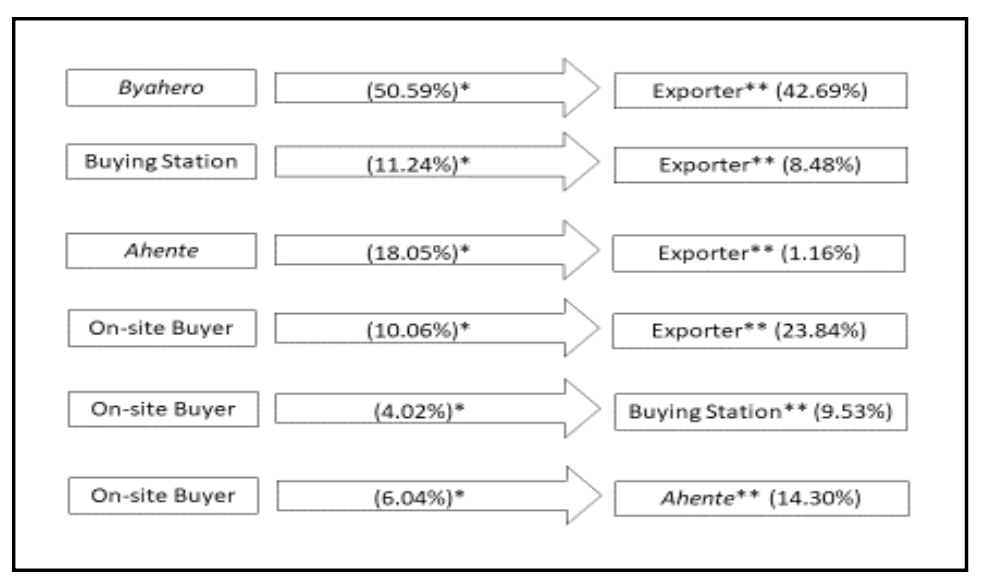

Figure 4. Market chain used by middleman traders to trade marine ornamental fish with exporters

Note: ${ }^{\star}$ Figures within the parentheses indicate percentage of middleman-trader using the marketing channe, ${ }^{* *}$ Figures within the parentheses indicate percentage of ornamental fish traded by the middleman- trader using the market channel

that majority of middleman were byaheros (50.59\%) mainly from Regions 3 (Zambales), 4A (Batangas and Quezon, and 4B (Marinduque). This middleman passed on to the exporters about $42.69 \%$ of the fish purchased from the divers. The byaheros gained 10$20 \%$ commission from the diver-gatherer and another $5-10 \%$ commission and trucking allowance from the exporter. The second largest type of middleman were on-site buyers $(20.12 \%)$ which traded $20.12 \%$ of total ornamental fish. On-site buyers gained 20$30 \%$ from the purchase of fish from diver-gatherers but shouldered all expenses of the transport to the exporters. In many cases, on-site buyers financed the operating costs of contracted groups of diver-gatherers to ensure that all fish collected will be sold to them. All operating expenses, however, were deducted from the diver-gatherer sales of fish. Of these fish traded by on-site buyers, $23.84 \%$ were sold directly to the exporters while $9.53 \%$ were sold to buying stations, and $14.30 \%$ to ahente. On-site buyers were present in all regions. Buying stations were present in Regions 2 (Cagayan) and 4A (Quezon). Furthermore, 18.05\% of the middleman-traders were ahente who traded $1.16 \%$ of the total ornamental fish. Buying stations traded $8.48 \%$ of the total ornamental fish.

Exporters were the final destination of marine ornamental fish traded in the country. There were 48 backyard and commercial export companies located in both the National Capital Region (NCR) and Cebu, the majority of which is located in Las Piñas and Pasay. Cebu City and Lapu-Lapu City were main trade centers for fishes coming from Visayas and Mindanao. The countries they export to were more or less similar, the United States of America is the biggest market, followed by China. It can be observed that the peak month of export trade was in March while the lowest transaction was during August. Assuming trade conditions remained constant coupled with provision of appropriate government interventions to further improve the industry, the trade value of marine ornamental fish may continue to increase as the years pass by. Usually, the selling price of marine ornamental fish by the exporter to consignees abroad were about three to five times the exporter's price rate purchased from the diver-gatherer or middleman.

3.3 Cost Distribution and Value Addition along the Chain

The cost distributions per individual stakeholder based on the stakeholders' annual amount of transactions of production and trade is presented in Table 4. The diver-gatherer approximately spent PHP 124,026.93 $\pm 92,910.55$, middleman-trader with PHP 206,048.90 $\pm 124,619.04$, and exporters with PHP $118,124,262.00$.

For the diver-gatherer, the bulk of expenditures came from labor and variable costs whereas for the middleman this came from procurement and transportation. Exporters spent the most on procurement cost and utilities (i.e. water, rent, electricity). In the case of Regions 5, 7, and 11, most suppliers shouldered the costs of diving equipment, food, and boats of the divers/gatherers. Additionally, they also paid the transport cost of fish from the source to either Manila or Cebu where exporting companies are based. The latter was expected to have the highest costs due to the large capital outlay. Based on the analysis of the data, it could be inferred that expenditures increase as the commodity moves up the chain. The aforementioned regions have undoubtedly benefitted most out of their arrangements. The most straightforward supply chain can be found in Region 7 where the majority of divers go directly to the suppliers whereas Regions $4 \mathrm{~A}$ and 11 have the advantage of variety. The shift to the latter three groups have also 


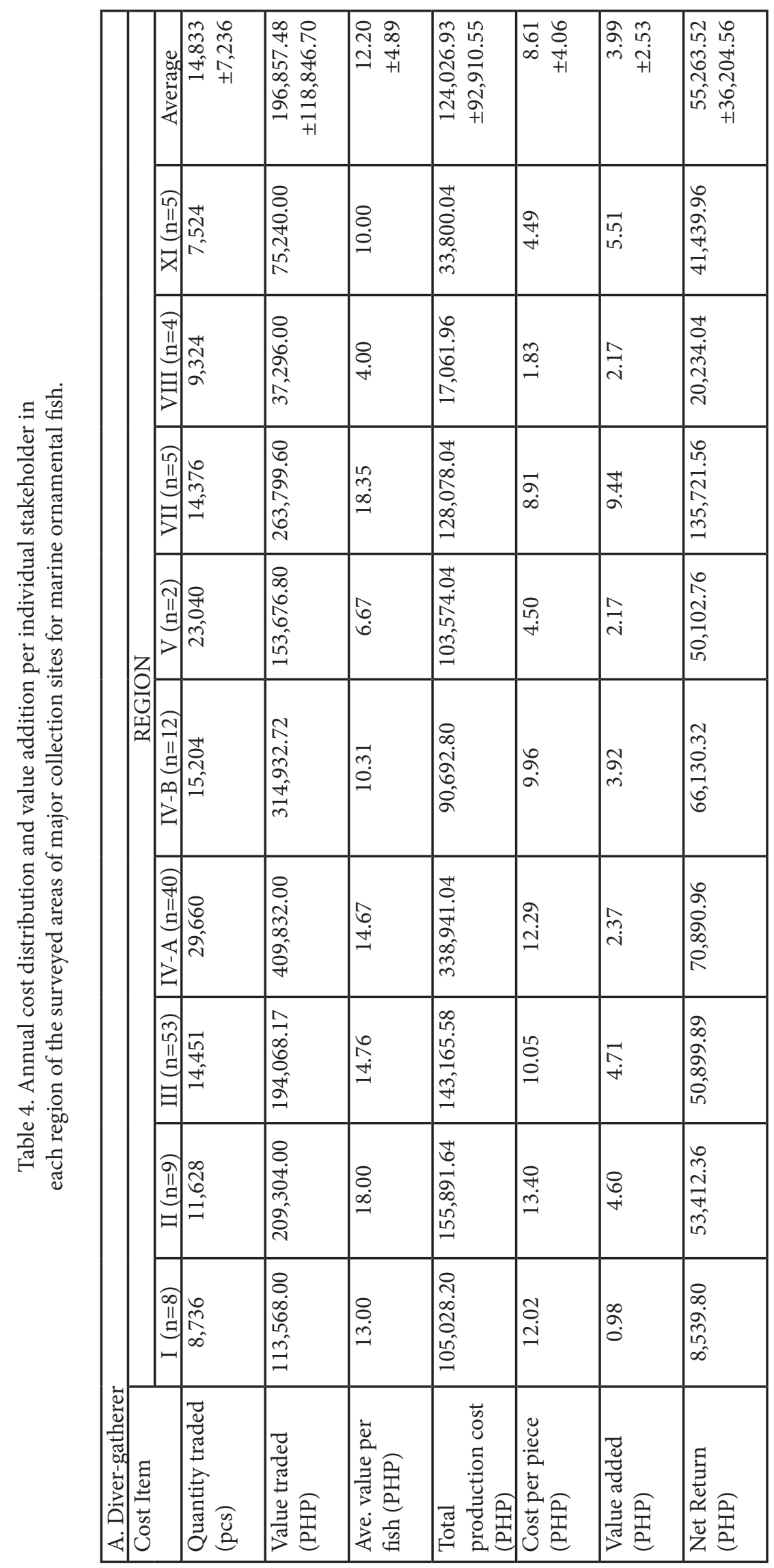




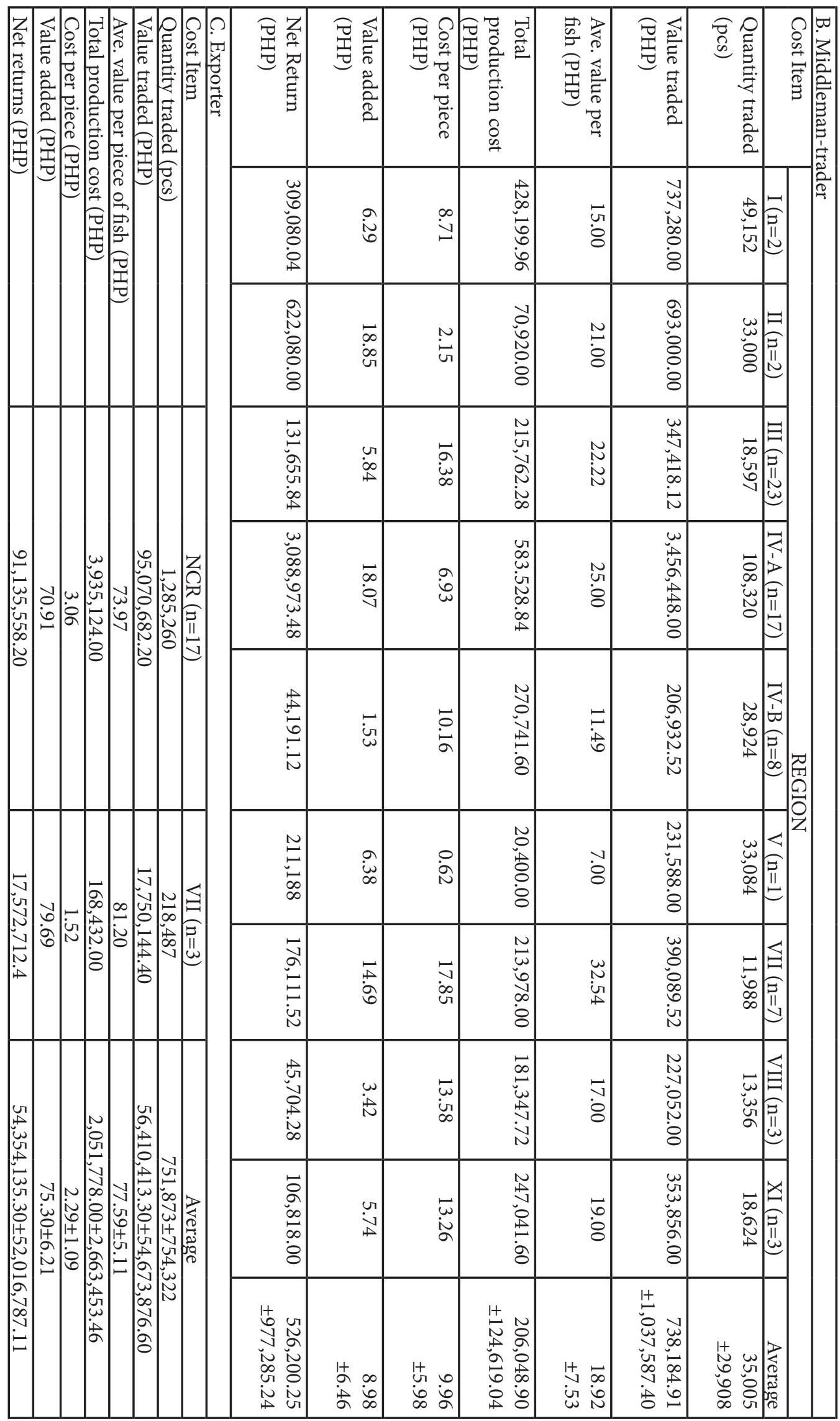


been brought about by the trade demographics in the area since Regions 4A and 2, in particular, have buying centers in one of their major collection areas, i.e., Cagayan and Quezon.

The first actor in the chain, the diversgatherers, have a value addition of PHP 3.99 \pm 2.53 . This increased to PHP $8.98 \pm 6.46$ as the fish goes on to the middleman while the exporter has a drastic increase of value-added worth PHP 75.30 \pm 6.21 (Table $4)$. In the course of the value addition along the chain from the diver to the supplier and/or exporter, the gross wealth created was equal to PHP 88.27. The progression of value addition was noted as it goes along the chain, implying the increasing use of inputs as the commodity moves from one actor to another. The diver-gatherer has no procurement cost for the fish since it is harvested from the wild. The only inputs they would have to spend would be the intermediate ones as they bring the fish to the middleman-trader. The on-site buyer, ahente or byahero, spent the same intermediate inputs to make sure the fish was alive and maintained. Finally, exporters have the largest value-added cost since they spend much for capital outlay such as big facilities and equipment necessary to maintain the quality of the fish qualified for export. Some of these large machines are protein skimmers, UV filters, elaborate water systems, air blowers, and other essential equipment. Across regions, the value additions were also affected by trade demographics. A notable example was of export companies between Region 7 and NCR with the former having a higher value despite the latter comprising the major bulk of marine ornamental fish trade in the country. While the export companies in both regions use equipment, Region 7 might have employed larger facilities and more machines to maintain the quality of fish and ensure its longevity thereby increasing its value addition for the said commodity.

Analysis of the value additions across regions and per stakeholder showed that among diversgatherers, Regions 7, 4A, and 11 have the top three highest value additions. On the other hand, among middleman-trader, Region 4A, 2 and 7 had the highest value addition. In terms of the exporting companies' value additions, Region 7 has higher value addition than NCR. A cost-return analysis validated the results of the value addition wherein the stakeholder having the highest value-added also reaped the most out of the value chain.

\subsection{Species collected and traded}

Marine ornamental fish were all collected by the diver-gatherers from coral reef areas through skin diving using nets and traps. Diver-gatherers operated in small groups of one to two small banca with two to three diver-gatherers or in big groups with three or more large boats with more than 10 diver-gatherers.

The former operated in nearshore areas while the latter group fished in distant waters. Divergatherers would skin dive into the reef areas and collect fish using a variety of nets and traps. Nets were surrounded around corals with the target fish. The fish was then collected using scoop nets and transferred into a plastic container attached to the diver-gatherer's waist. For species that were difficult to catch using nets, traps were used to lure the fish. Fish were then aggregated in modified containers placed in the banca and transported to diver-gatherers home. Generally, fishes were packed individually in oxygenated plastic bags, which were replaced with new water and refilled with oxygen every day until the date of transport. In some areas like Calatagan, Batangas, fish collected by diver-gatherers were stocked in small net enclosures prior to transport. They were placed in individual plastic bags only upon the day of transport. Mortalities and rejects were usually higher in the latter method because fish tend to be injured due to scraping on the net enclosures especially during strong wave action.

Based on the secondary data from BFAROSDEC (2015), there were 1,200 species of marine ornamental fish traded in the ornamental fish industry belonging to 144 Families and 67 fish groups. These include fish (46 families, 31 groups, and 904 species), invertebrates ( 8 families, 8 groups, and 247 species) and miscellaneous species (30 Families, 28 groups, and 49 species). On the other hand, actual survey interview of divers and middleman traders recorded a total of 426 species composed of 71 Families, 43 Groups (35 Fish Groups and 8 Invertebrate Groups). More than 800 species of marine ornamental fish that were listed in BFAR exported species were not recorded during the survey interview. These unrecorded fishes were not collected during the survey interview due to the seasonality of the species. It is therefore important that further studies must be done to verify the presence of these species in the collection areas at the diver- 
gatherer's level. Based on the survey interview data of actual species collected by the diver-gatherers, the largest groups were: Labridae (hogfishes with 73 species), Pomacentridae (clownfishes, chromis and damselfishes with 44 species), Chaetodontidae (butterflyfishes with 36 species), Pomacentridae (angelfishes with 26 species), Gobiidae (gobies with 22 species), Acanthuridae (tangs with 20 species), Serranidae (anthias and groupers with 19 species), and Serpulidai (anemones with 13 species). In contrast, the list of exported marine ornamental fish (BFAR-OSDEC 2015) showed that largest groups were: Wrasses (106 species), Gobies (70 species), Damselfishes (46 species), Butterflyfishes (36 species), Grouper/Pseudochromis (36 species), Anthias (32 species), Angelfishes (28 species), Blennies (27 species) Anemones (32 species), and Shrimps (32 species). All of the marine ornamental fish were native to the country and were gathered from the wild. There was no record of captive breeding of marine ornamental fish that had been documented in the study. Among marine ornamental species, the highest number of quantity traded were green chromis (6.69\%), false percula clownfish (4.61\%), firefish goby (3.35\%), damselfish $(2.97 \%)$, pacific neon goby $(2.69 \%$, and three-stripe damselfish (2.66\%).

The collection areas of the regions intersect from time to time, but the variety of places and the almost nomadic nature of the stakeholders were noticeable. About $47.1 \%$ of diver-gathers and 51.5\% of middleman-traders were not natives of the area they were currently residing. The demographics of collection areas can also play a part in the supply chain of the industry. There were numerous areas before, in the case of Samar and Leyte, but these were closed upon implementation of the municipal ordinance (MO) banning the use of compressors and ornamental fish trade. Capul Island was an exception which implemented the ordinance at the local government's discretion. At present, marine sanctuaries were put up in many areas to ensure the sustainability of marine resources.

Production of marine ornamental fish was dictated by the demand from exporters who were largely dependent on demand orders from importing countries. The large proportion of production of marine ornamental fish in three major regions was largely attributed to the presence of wide coral reef areas and the correspondingly large number of divergatherers. Production was limited in some areas by regulations on banning the collection of marine ornamental fish due to the suspected use of cyanide, as in the case of Zambales in Central Luzon and Northern Samar in Eastern Visayas, and on banning the use of compressor imposed in almost all of the collection areas. Extreme weather conditions in the months of September-February also limited the collection from the wild.

Presently, there is a pressing concern with the marine ornamental fish industry sector particularly on the sustainability of resources over the continued gathering of the fish from the wild. Table 5 a showed the IUCN category of the marine ornamental fish recorded in the survey interview as collected by divergatherers. Among the 426 marine ornamental fish species recorded from the study, 165 species were categorized by IUCN as not yet assessed; 210 species were of least concern; 39 species were uncategorized; 10 species were data deficient; 1 vulnerable species; 2 species as near threatened; and 1 species as endangered. Among this list, four species were of primary concern (Table 5b), which included Acanthurus chronixis (vulnerable); Chiloscyllium plagiosum and Carcharhinus melanopterus (near threatened); and Cheilinus undulatus (endangered). This IUCN category is a global assessment, thus, a national red listing assessment of these species and the rest of the marine ornamental fish species is needed to determine its wildlife status and to provide scientific information to policymakers for the protection of threatened species. Under the Philippine law, specifically Republic Act 10654 Section 102, CITES-listed species are protected and prohibited from being extracted from the wild. The actual collection sites of the aforementioned IUCN red-listed species have been identified in the study, however, verification of the information is needed through the actual collection of live samples and corresponding taxonomic identification. If indeed these species are caught in the areas, appropriate policy regulations must be enacted and enforced. There may be a lack of awareness on this issue on the part of the diver-gatherers and the local government units, thus, awareness campaigns must be strengthened to prevent the collection of these red-listed species. This concern is similar to other countries with marine ornamental fish extraction from the wild, which recorded several species that need regulations (Prakash et al. 2017; Madduppa et al. 2014). Furthermore, coral reef areas in Luzon and Visayas were generally in the poor or fair category (Licuanan et al. 2017; Aliño et al. 2012). This state of reef areas and the collection of marine ornamental fish put strong pressure on the wild population and may result in its further decline. In many countries with similar trade situation for marine 
Table 5a. Global IUCN status of marine ornamental fish gathered by divers in major collection areas in the Philippines recorded in actual survey of the study

\begin{tabular}{|l|c|}
\hline IUCN Category & Number of species \\
\hline Not yet assessed but found in Catalogue of Life & 123 \\
\hline Not yet assessed and not in the Catalogue of Life & 42 \\
\hline Least concern - population trend unknown & 118 \\
\hline Least concern - population trend stable & 83 \\
\hline Least concern - population trend decreasing & 7 \\
\hline Least concern - population trend increasing & 2 \\
\hline Data deficient - population trend unknown & 4 \\
\hline Data deficient - population trend stable & 1 \\
\hline Data deficient - population trend decreasing & 3 \\
\hline Data deficient - population trend increasing & 2 \\
\hline Vulnerable - population unknown & 1 \\
\hline Near Threatened - population unkown & 1 \\
\hline Near threatened - population trend decreasing & 1 \\
\hline Endangered - population trend decreasing & 1 \\
\hline Uncategorized (no scientific name; common name only) & 39 \\
\hline Total & 426 \\
\hline
\end{tabular}

Table 5b. List of vulnerable, near threatened, and endangered species of marine ornamental fish recorded in the actual survey of the study based on global IUCN status

\begin{tabular}{|l|l|c|c|c|}
\hline \multicolumn{1}{|c|}{ IUCN Category } & $\begin{array}{r}\text { Scientific name } \\
\text { (Fishbase) }\end{array}$ & $\begin{array}{c}\text { English name } \\
\text { (Fishbase) }\end{array}$ & $\begin{array}{c}\text { Common name } \\
\text { (BFAR-OSDEC) }\end{array}$ & $\begin{array}{c}\text { Recorded } \\
\text { collection site }\end{array}$ \\
\hline $\begin{array}{l}\text { Vulnerable - } \\
\text { population trend } \\
\text { unknown }\end{array}$ & Acanthurus chronixis & $\begin{array}{c}\text { Chronixis } \\
\text { surgeonfish }\end{array}$ & $\begin{array}{c}\text { Half black/Mimic } \\
\text { tang }\end{array}$ & $\begin{array}{c}\text { Region 1 and } \\
\text { Region 4A } \\
\text { (Isla Verde, } \\
\text { Batangas) }\end{array}$ \\
\hline $\begin{array}{l}\text { Near Threatened - } \\
\text { population trend } \\
\text { unknown }\end{array}$ & Chiloscyllium plagiosum & $\begin{array}{c}\text { White spotted } \\
\text { bamboo shark }\end{array}$ & $\begin{array}{c}\text { Banded catshark- } \\
\text { Plagiosum }\end{array}$ & $\begin{array}{c}\text { Region 2 } \\
\text { (Cagayan) }\end{array}$ \\
\hline $\begin{array}{l}\text { Near Threatened - } \\
\text { population trend } \\
\text { decreasing }\end{array}$ & Carcharhinus melanopterus & & $\begin{array}{c}\text { Black tip reef } \\
\text { shark }\end{array}$ & $\begin{array}{c}\text { Region 3 } \\
\text { (Masinloc) }\end{array}$ \\
\hline $\begin{array}{l}\text { Endangered - } \\
\text { population trend } \\
\text { decreasing }\end{array}$ & Cheilinus undulatus & Humphead \\
wrasse & $\begin{array}{c}\text { Humphead } \\
\text { wrasse - Tropical } \\
\text { mameng }\end{array}$ & $\begin{array}{c}\text { Region 3 (Sta. } \\
\text { Cruz) }\end{array}$ \\
\hline
\end{tabular}

ornamental fish gathered from the wild, a significant decrease in wild populations was reported (Bruckner 2005; Wood 2001). Sustainable harvesting of fish is, therefore, important to ensure continued productivity over a long-term period. However, there are no clear policy regulations on collection of marine ornamental fish in the country although some local government units impose restrictions or ban on gathering and/ or transporting marine ornamental fish, such as in
Zambales and Northern Samar. These restrictions, however, had negative implications on the livelihood of the diver households who had no other source of income but marine ornamental fish gathering.

Marine ornamental fish gathering from the wild could be limited by the available resources in the wild, making production unsustainable and unpredictable. Thus, there is a need for an alternative source other than the wild. Marine ornamental fish 
aquaculture, the breeding and production of fish in captivity, is an emerging opportunity in the sector. In other countries, production of captive-bred species of marine ornamental fish had augmented their export trade which lessened pressure on the said species (Domínguez and Botella 2014; Kumar et al. 2015). Captive breeding is a sustainable means of production and the demand for captive-bred fish is increasing due to ecological concerns related to wild-caught fishes. At present, there are about 338 species of marine ornamental fish and invertebrates that had been reported as captive-bred and 36 species were known to be commonly available in the ornamental fish trade (Swet and Pedersen 2018). Captive-breeding of marine ornamental fish, however, is still in its infancy with multiple bottlenecks limiting marine ornamental aquaculture (Moorhead and Zeng 2010). At present, the Philippines has no record of captive breeding of marine ornamental fish traded for the export market. Thus, the country needs to start its breeding program for marine ornamental fish to be able to enter the captive-bred market and sustain its export in the future.

\subsection{Constraints and Management}

The marine ornamental fish sector is confronted by two basic issues, one that concerned the diver-gatherer, and another which is related to resource sustainability and management. On the side of the diver-gatherers, main issues were low income as a result of long marketing chain, LGU regulations on collection of fish, and lack of livelihood during periods when fishing is not possible. The availability of buying centers in the areas like Regions 4A (Real, Quezon) and 2 (Sta. Ana, Cagayan) proved to be the most advantageous to the diver-gatherers and thus, should be replicated by the exporters in other areas where the income of diver-gatherers was low. The increased benefit from the higher selling price of fish would lessen the number of fish targeted by the diver-gatherers which aimed to meet the daily needed income of the family. Municipal ordinances on the banning of compressor-type diving equipment and the banning of collection and trade of ornamental fish were implemented in the following areas: Bolinao, Pangasinan; Sta. Ana, Cagayan; Sta. Cruz, Masinloc; Palauig and Subic, Zambales; Isla Verde, Batangas; Magcaraguit Island, Masbate; Olango Island, Cebu; and Capul Island, Samar. The ban on the use of compressors was generally aimed to protect the divers from the hazard posed by unsafe compressor- type diving apparatus. In such cases, there is a need to equip the diver-gatherers with appropriate diving apparatus that is safe for diving, affordable, and costefficient. Due to the high cost of the diving equipment, there must be a financial scheme for diver-gatherers to avail such equipment either through loan assistance from the government or provision from the exporters. In several areas where the ban on the collection and trade of ornamental fish is implemented, the LGUs determined that the resources are under threat and must be regulated. However, the affected diver-gatherers must be given access to alternative livelihood to ensure that they do not return to the illegal gathering of marine ornamental fish. Furthermore, alternative livelihood must be available to the diver-gatherers during periods when fishing is not possible to alleviate their living conditions and prevent them from incurring large debts. On the side of the middleman-traders, apprehensions by law enforcement authorities had been reported despite presenting transport permits issued by concerned LGUs. Presently, there is no clear policy on the required documents for trade and transport of marine ornamental fish. This must be enacted to preempt issues resulting in apprehensions. Moreover, the policy must ensure that transport permits are issued in municipalities certified by barangay officials where the transported fishes were collected. This is to prevent the collection of fishes from areas of no-take zones and/or municipalities with the existing ban on the collection and trade of marine ornamental fish. LGUs must also issue certifications of accredited middleman-traders in the localities to ensure accountability. In certain areas like Isla Verde (Region 4A), coastal barangays did not permit non-residents from gathering ornamental fish in their locality although the barangays does not have jurisdiction over their waters since it is categorized as municipal water. By law, such water is accessible to residents of the municipality and not limited to barangay residents. This issue is an internal problem and may be resolved within the municipality of concern. Generally, there was a misconception held by the majority of the public that marine ornamental fish trade is entirely illegal. Davao, on the other hand, enjoyed the steady market, abundance of species, and less competition but like other provinces, it also faced the usual concerns on weather, mortality, disease and disease control, and delayed payments.

On resource sustainability and management, national policy on the regulations of marine ornamental fish collection and trade is limited to ban the collection and trade of rare, threatened, 
Table 6. Upgrading strategies and action plan for the marine ornamental fish industry

\begin{tabular}{|l|l|l|}
\hline \multicolumn{1}{|c|}{ Strategies } & \multicolumn{1}{|c|}{ Definition } & \multicolumn{1}{c|}{ Action Plan } \\
\hline 1. Horizontal coordination & $\begin{array}{l}\text { Development of relationships among } \\
\text { stakeholders for stronger coordination, } \\
\text { reduction in transaction costs and } \\
\text { increase in economies of scale }\end{array}$ & $\begin{array}{l}\text { Formation of a collective structure } \\
\text { of organization for divers/ } \\
\text { gatherers and middlemen per area }\end{array}$ \\
\hline 2. Vertical coordination & $\begin{array}{l}\text { Develops interaction between upstream } \\
\text { and downstream players }\end{array}$ & $\begin{array}{l}\text { Exporters contract diver or } \\
\text { suppliers and directly get supply } \\
\text { from them }\end{array}$ \\
\hline 3. Product upgrading & Improves product quality & $\begin{array}{l}\text { Trainings on product handling } \\
\text { and packaging }\end{array}$ \\
\hline 4. Process upgrading & Makes chain cost-effective and efficient & Campaign to stop cyanide-fishing \\
\hline 5. Functional upgrading & $\begin{array}{l}\text { Mix of functions occur or removal of } \\
\text { intermediaries; shortening of the chain }\end{array}$ & $\begin{array}{l}\text { Contract between stakeholders; } \\
\text { similar to vertical coordination }\end{array}$ \\
\hline 6. Chain upgrading & New skills are applied to the chain & $\begin{array}{l}\text { Captive breeding of marine } \\
\text { ornamental fish }\end{array}$ \\
\hline $\begin{array}{l}\text { 7. Upgrading of 'enabling' } \\
\text { environment }\end{array}$ & $\begin{array}{l}\text { Cooperation of local government units } \\
\text { (LGUs) since this would tackle trade } \\
\text { policies and management plans }\end{array}$ & $\begin{array}{l}\text { Licensing requirements, strict } \\
\text { penalties, and marine reserves to } \\
\text { ensure the sustainability of the } \\
\text { livelihood }\end{array}$ \\
\hline
\end{tabular}

and endangered species as listed in the CITES as stipulated in the RA 8550 (Philippine Fisheries Code of 1998) as amended by Republic Act 10654. In several countries with marine ornamental fish trade, sustainability and conservation of wild populations are ensured through existing regulations on the quota system for collection of marine ornamental fish such as in Maldives (Edwards and Shepherd 1992), Palau (Graham 1996), Puerto Rico (Hardin and Legore 2005), Queensland (Queensland Government 2009), and Australia (Commonwealth of Australia 2006). The Philippines must replicate these policies to conserve, protect, and manage its local marine ornamental fish species. Furthermore, diver-gatherers who use legal fishing methods of collection of ornamental fish must be accredited by respective LGUs to prevent illegal means of collection. More importantly, the quantity and species that are collected from the wild by the diver-gatherers and are traded for the ornamental fish trade are generally dictated by the marine ornamental fish exporters, thus, a national policy for the industry must concentrate largely on this player.

\subsection{Upgrading Strategies}

Diver-gatherers and middleman-traders, categorized as fisherfolk, have a poverty incidence of $34.0 \%$ in 2015 (PSA 2016). In most regions, they were wholly dependent on marine ornamental fish collection except in Regions 11 (Davao) and 8 (Samar and Leyte) where income from the ornamental fish gathering was augmented by other means of livelihood. The two FGDs generated inputs that were integrated to come up with upgrading strategies and action plan designed to maximize the full benefits of the industry to each of the actors and the sector as a whole (Table 6). To uplift the living conditions of the first two actors, the chain must undergo upgrading strategies, but it is to be noted that changes to other sources of income beyond the value chain may offset the gains brought by these strategies. Upgrading may come in seven forms: horizontal coordination, vertical coordination, product upgrading, process upgrading, functional upgrading, chain upgrading, and upgrading of enabling environment (Mitchell et al. 2009). Table 6 explains each strategy and suggests specific action plans for each that are also in line with the given suggestions of respondents during the tracer study and FGDs. Ultimately, the strategies point to the relationships among actors and external players such as LGUs in order to boost the industry, maximize its potential, and ensure sustainability.

\section{CONCLUSION}

Marine ornamental fish industry has been earning worldwide interest and demand, an opportunity that the Philippines must grab to be at 
par with other exporting countries. The study showed that 1,431 households were directly dependent on the industry composed of major stakeholders categorized as diver-gatherer, middleman-trader (on-site buyer, byahero, ahente), and exporters. The general supply chain follows the commodity from diver-gatherer to a middleman-trader and, finally, to an exporter. The value addition along both chains followed a progression: the divers-gatherers have a value addition of PHP $3.99 \pm 2.53$, the middlemen have PHP $8.98 \pm 6.46$ while the exporters have PHP $75.30 \pm 6.21$. The overall chain created a total wealth of 90.53 per piece of marine ornamental fish. When observed across regions, Region 7 (PHP 103.82) has the highest value addition while Region $4 \mathrm{~B}$ (PHP 5.45) has the lowest. The outcome of the value chain analysis of the ornamental fish industry puts the first node stakeholders - the divers-gatherers and producers - at the bottom of the trade, having contributed the least value addition and received the least return.

A substantial number of stakeholders are dependent on the industry, but with minimal data available, extension services and assistance are seldom handed out. There exists no mechanism to ensure uniform market information distribution. Those who do not receive the information are thus further disadvantaged. Additionally, fisherfolk have to deal with the lack of transparency on price transformation, asymmetric information, limited capital, and poor postharvest infrastructure. The stakeholders still face problems such as lack of diving equipment, lack of cheap alternatives for banned compressor type diving apparatus, delayed payments, fish mortality, and difficulty in acquiring collection permits. Government interventions are encouraged, particularly on the issuance of appropriate permits and providing assistance for equipment and credit. Strengthening fisherfolk organizations and encouraging memberships are two of the many ways to help improve the livelihood of the fisherfolk involved in the industry. Additionally, seminars and training may be reinforced to enhance the skills and knowledge of the stakeholders which would ultimately benefit the marine ornamental fish industry in the country. Moreover, government agencies must encourage exporters to observe equitable pricing of fish at the diver-gatherer's level to improve the level of livelihood and to prevent excessive harvesting of fish to meet needed income. Finally, there is no clear policy on collection of marine ornamental fish from the wild and it is important that such measures are enacted to ensure the sustainability of the fish populations in the wild and the marine ornamental fish industry that depends on these resources.

\section{A C KNOWLED GMENTS}

The authors are grateful to the National Fisheries Research and Development Institute for funding the Ornamental Fish Project of FFRDC. The authors also thank all BFAR regional offices, local government units, and respondents that supported the conduct of survey interviews and FGDs, as well as to the BFAR-FRQD and BFAR Fish Health Main Office. Sincerest gratitude is also expressed to the anonymous reviewers of this paper.

\section{RE F E R E N C E S}

Aliño PM, Nañola Jr CL, de Jesus DD, de Ramos RI, Balingit ACM, Robles LE, Arceo HO, Deocadez MR, Atrigenio M, Martinez RJS et al. 2012. Status of Philippine coral reefs (2008-2011). In: Baria V, Muallil R, de Jesus DO, Samonte P, Ricafrente MV, Arceo H, Aliño PM editors. State of coasts: Sustaining the state of the coasts reporting. Quezon City: PhilReefs, Philippine Council for Agriculture, Aquatic and Natural Resources Research and Development and the Marine Science Institute, University of the Philippines. p. $10-15$

[BFAR-OSDEC] Bureau of Fisheries and Aquatic Resources-One Stop Export Documentation Center. 2015. Secondary information on marine ornamental fish export data. Pasay City: Bureau of Fisheries and Aquatic Resources.

Bruckner AW. 2005. The importance of the marine ornamental reef fish trade in the wider Caribbean Rev. Biol. Trop. Int. J. Trop. Biol. ISSN-00347744. 53 (1): 127-138.

[CNFIDP] Comprehensive National Fisheries Industry Development Program. 2016. Comprehensive National Fisheries Industry Development Program 2016-2020. Quezon City. Bureau of fisheries and Aquatic Resources.

Commonwealth of Australia. 2006. A Strategic Approach to the Management of Ornamental Fish in Australia. Department of Agriculture, Fisheries and Forestry. Commonwealth of Australia [Internet]. [cited 2018 June 9]. Available 
from: https://www.dpi.nsw.gov.au/

Domínguez LM, Botella AS. 2014. An overview of marine ornamental fish breeding as a potential support to the aquarium trade and to the conservation of natural fish populations. Int. J. Sus. Dev. Plann. 9(4): 608-632.

Dey VK. 2016. The Global Trade in Ornamental Fish. INFOFISH International [Internet]. [cited 2018 June 9]. p. 55-55. Available from: http//:www. infofish.org.

Edwards AJ, Shepherd AD. 1992. Environmental implications of aquarium-fish collection in the Maldives, with proposal for regulation. Environmental Conservation. 19(01):61-72.

[FAO] Food and Agriculture Organization. 2015. Food and Agriculture 2015. Ornamental Fish. [cited 2018 June 9]. Available from: http//:www. fao.org.

Graham T. 1996. Managing Palau's aquarium life fishery. SPC Live Reef fish Information Bulletin \#1. March 1996. p. 13-18.

Herath HMTNB, Wijewardene LN. 2014. Ornamental fish trade in Sri Lanka: an economic perspective. International Journal of Environmental Sciences. 3(8): 40-45.

Hardin MP, Legore, RS. 2005. Development of management policy for the marine ornamental fish and invertebrate fishery in Puerto Rico: a case study. Rev Biol Trop. 53(1): 139-144.

Kumar ATT, Gunasundari V, Prakash S. 2015. Breeding and Rearing of Marine Ornamentals. Advances in Marine and Brackishwater Aquaculture 101$107 \mathrm{p}$.

Licuanan AM, Reyes MZ, Luzon KS, Chan MAA, Licuanan WY. 2017. Initial findings of the nationwide assessment of Philippines coral reefs. Philippine Journal of Science 146(2): 177-185.

Ling H, Lim LY. 2005. The status of ornamental fish industry in Singapore. Singapore J Pri Ind 32: 5969.

Livengood EJ, Chapman FA. 2009. The ornamental fish trade: An introduction with Perspective for responsible aquarium cooperative extension service. Institute food and agricultural science, University of Florida Gainesville FL, 32611, p.230.

Madduppa HH, Juterzenka KV, Shakir M, Kochzius M. 2014. Socio-economy of marine ornamental fishery Amphiprion occelaris and its host anemones in Spermonde Archipelago, Indonesia. Ocean \& Coastal Management 100: 41-50.

Mitchell J, Keane J and Coles C. 2009. Trading Up: How a Value Chain Approach Can Benefit the Rural People. COPLA Global: Overseas Development Institute. London, UK.

Moorhead JA, Zeng C. 2010. Development of Captive Breeding Techniques for Marine Ornamental Fish: A Review. Reviews in Fisheries Science. 18(4):315-343.

Orchavillo D, Hodgson G, Shuman C, Ruz R. 2004. Status of the Philippine marine aquarium fish trade. In: DA-BFAR (Department of AgricultureBureau of Fisheries and Aquatic Resources). In turbulent seas: The status of Philippine marine fisheries. Coastal Resource Management Project, Cebu City, Philippines. p. 378.

Prakash A, Kumar TTA, Raghavan R, Rhyne A, Tlusty MF, Subramonian T. 2017. Marine aquarium trade in India: Challenges and opportunities for conservation and policy. Marine Policy. 77: 120129.

[PSA] Philippine Statistics Authority. 2016. Philippine Fisheries Situationer 2009 to 2016. Philippine Statistics Authority. p. 47. [Internet]. [cited 2018 June 9]. Available from: https://psa.gov.ph/sites/ default/files/FisheriesSituationer2016_0.pdf.

Queensland Government. 2009. A Guide to the Queensland Marine Aquarium Fish Fishery and the Queensland Coral Fishery. The state of Queensland, Department of Employment, Economic Develooment and Innovation. p. 15.

Swet T, Pedersen M. 2018. A Coral Special Report: The State of Marine Breeder's Art, 2018. Coral Magazine March/April 2018 issue. 
Teddlie C, Yu F. 2007. Mixed Methods Sampling: Wood EM. 2001. Collection of coral reef fish for A Typology with Examples. Journal of Mixed aquaria: Global trade, conservation issues and Methods Research, 77-100. management strategies; Marine Conservation Society, Ross-on-Wye, UK. 